\title{
Determinan Struktur Modal dan Nilai Perusahaan
}

\author{
Mukmin Pohan, Maya Sari", Adi Munasib, Radiman \\ Fakultas Ekonomi dan Bisnis, Universitas Muhammadiyah Sumatera Utara \\ Jl. Kapten Mukhtar Basri No. 3 Medan 20221, Indonesia
}

*Koresponden: mayasari@umsu.ac.id

\author{
Artikel Info \\ Received: \\ 3 September 2020 \\ Revised: \\ 18 Oktober 2020 \\ Accepted: \\ 30 Oktober 2020
}

Published by Jurnal Ilmiah Manajemen dan Bisnis, Indonesia | Copyright (c) 2020 by the Author(s) | This is an open access article distributed under the Creative Commons Attribution License

http://creativecommons.org/licenses by/4.0), which permitsunrestricted use

distribution, and reproduction in any medium, provided the original work is properly cited.

\begin{abstract}
ABSTRAK
Tujuan umum dari penelitian ini adalah merumuskan model determinan struktur modal dan nilai perusahaan. Populasi penelitian ini adalah perusahaan sektor industri Pariwisata yang terdaftar di Bursa Efek Indonesia periode tahun 2013-2018. Dalam penelitian ini keseluruhan populasi dijadikan sample (Total Sampling). Pengumpulan data dengan mengumpulkan data laporan keuangan (annual report) yang sudah diaudit (audited). Teknik analisis data adalah analisis jalur (path analysis). Hasil penelitian menunjukkan bahwa secara parsial profitabilitas, kepemilikan institusi dan ukuran perusahaan berpengaruh signifikan terhadap struktur modal sedangkan pertumbuhan perusahaan tidak berpengaruh signifikan terhadap struktur modal. Secara simultan variabel profitabilitas, kepemilikan institusi, pertumbuhan perusahaan dan ukuran perusahaan berpengaruh terhadap struktur modal. Secara parsial profitabilitas, kepemilikan institusi, ukuran perusahaan dan struktur modal berpengaruh signifikan terhadap nilai perusahaan, sedangkan pertumbuhan perusahaan tidak berpengaruh signifikan terhadap nilai perusahaan. Secara simultan profitabilitas, kepemilikan institusi, ukuran perusahaan, pertumbuhan perusahaan dan struktur modal berpengaruh signifikan terhadap nilai perusahaan pada perusahaan sektor industri Kepariwisataan.
\end{abstract}

Kata Kunci: Kepemilikan Institusi, Ukuran Perusahaan, Pertumbuhan Perusahaan, Struktur

\section{Determinants of Capital Structure and Firmp Value}

\begin{abstract}
The purpose of this study is to formulate a determinant model of capital structure and firm value. The population of this study is the tourism industry sector companies listed on the Indonesia Stock Exchange for the period 2013-2018. In this study the entire population is sampled (Total Sampling). Data collection procedures by collecting audited (annual report) financial report data issued by the Indonesia Capital Market Directory (ICMD). The data analysis technique used is path analysis. The results showed that partially profitability, institutional ownership and firm size had a significant effect on capital structure while company growth had no significant effect on capital structure. Simultaneously the profitability variables, institutional ownership, company growth and company size affect the capital structure. Partially profitability, institutional ownership, company size and capital structure have a significant effect on firm value, while company growth does not significantly influence firm value Simultaneously profitability, Institutional ownership, company size, company growth and capital structure have a significant effect on company value in the sector tourism industry.
\end{abstract}

Keywords: Profitability, Institutional Ownership, Firm Size, Company Growth, Capital Structure, Firm Value

DOI: https://doi.org/10.30596/jimb.v20i1.2991

JEL CLASSIFICATION: O, O1, 016

Cara Sitasi :

Pohan, M., Sari, M., Munasib, A., \& Radiman, (2020). Determinan Struktur Modal dan Nilai Perusahaan. Jurnal Ilmiah Manajemen dan Bisnis, 21(2), 105-122. https://doi.org/10.30596/jimb.v20i1.2991. 


\section{PENDAHULUAN}

Nilai perusahaan yang sangat penting bagi suatu perusahaan, karena jika nilai perusahaan tinggi itu akan diikuti oleh kemakmuran tinggi bagi para pemangku kepentingannya (Suharli, 2006). Nilai perusahaan mencerminkan evaluasi investor terhadap keberhasilan suatu perusahaan. Meningkatkan nilai perusahaan dibuat sebagai upaya untuk mempertahankan keunggulannya (Hermawan \& Maf'ulah, 2014) dan untuk menjaga kelangsungan operasionalnya sehingga para pemangku kepentingan mendapat keuntungan dan kemakmuran (Febrianti, 2012). Nilai perusahaan yang tinggi tidak hanya diperhatikan oleh perusahaan dan investor tetapi juga oleh para kreditor dan pemerintah (Herawaty, 2009). Nilai perusahaan berfungsi sebagai positif menandatangani untuk kreditor untuk memberikan pinjaman (Manoppo \& Arie, 2016). Apalagi itu juga mencerminkan bahwa perusahaan memiliki kemampuan tinggi dalam membayar semua kewajibannya sehingga kreditor akan aman atau terhindar dari risiko default. Kegagalan dalam memaksimalkan nilai perusahaan disebabkan oleh beberapa ketidakmampuan tegas dalam menerapkan faktor-faktor penentu nilai perusahaan (Ernawati \& Widyawati, 2015). Maksimalisasi nilai perusahaan sangat dipengaruhi oleh ketersediaan dan akses ke keduanya sumber dana perusahaan eksternal atau internal (Safitri, 2015).

Dalam upaya memaksimalkan nilai perusahaan, suatu perusahaan membutuhkan pendanaan yang memadai untuk mendukung operasionalnya. Untuk memenuhi kebutuhan pendanaan perusahaan dapat dipilih alternative sumber dana dari internal (modal sendiri) berupa modal saham dan laba ditahan dan sumber dana eksternal (modal asing) yang diperoleh dari hutang. Sumber internal adalah dana yang tersedia dari laba ditahan, sedangkan sumber eksternal adalah dana berasal dari kreditor dan investor. Dana berasal dari kreditor disebut hutang untuk perusahaan. Campuran hutang dan ekuitas disebut struktur modal (Brigham \& Daves, 2010). Besarnya struktur modal merupakan hal yang sangat penting diperhatikan oleh perusahaan kerena baik buruknya struktur modal akan mempunyai dampak langsung terhadap posisi finansial perusahaan yang pada akhirnya akan mempengaruhi nilai perusahaan. Perusahaan dapat meminimalkan resiko yang berasal dari hutang, dengan mengoptimalkan modal perusahaan yang berasal dari external yang sepenuhnya digunakan untuk pembiayan perusahaan sehingga dapat meningkatkan keuntungan perusahaan itu sendiri. Oleh karena itu dalam pemanfaatannya harus efisien sehingga dapat menjadikannya lebih optimal. Struktur modal yang baik adalah struktur modal yang bisa meminimumkan biaya modal rata-rata dan memaksimumkan nilai perusahaan. Terdapat beragam faktor yang berpengaruh terhadap strukur modal diantaranya adalah stabilitas penjualan, struktur aktiva, leverage operasi, tingkat pertumbuhan, profitabilitas, pajak, sikap manajemen, pengendalian, kondisi pasar, sikap pemberi pinjaman dan agen pemberi peringkat, Kondisi internal perusahaan, dan fleksibilitas keuangan (Brigham \& Houston, 2010). Kusuma, Suhadak, \& Arifin, (2012) serta Mas'ud, (2008) mengungkapkan faktor yang berpengaruh terhadap struktur modal diantaranya: tingkat pertumbuhan penjualan, rasio pinjaman, profitabilitas, besarnya suatu perusahaan, struktur aktiva, biaya distres keuangan (cost of financial distress).

Profitabilitas merupakan kemampuan perusahaan dalam operasionalnya untuk memperoleh keuntungan. Kemampuan perusahaan dalam menghasilkan laba akan menjadi salah satu factor penilaian perusahaan. Investor akan menilai perusahaan secara positif apabila ratio profitabilitas menunjukkan kenaikan, dengan demikian para kreditur, supplier dan investor yang merupakan stakeholder perusahaan akan menilai kinerja perusahaan dengan baik. Selain itu dengan profitabilitas yang baik maka perusahaan akan memiliki kemampuan membagikan dividen yang lebih besar kepada para pemegang saham sehingga akan berdampak positif terhadap kepercayaan mereka dalam menginvestasikan dananya pada perusahaan.

Disisi lain naik turunnya nilai perusahaan dapat dipengaruhi juga oleh struktur kepemilikan, diantaranya oleh kepemilikan institusi. Dengan kepemilikan institusi diyakini 
mampu memonitor manajemen dalam pengambilan keputusan keuangan, semakin besar kepemilikan institusi maka semakin efisien pemanfaatan aktiva perusahaan. Kepemilikan institusi adalah proporsi kepemilikan saham pada akhir tahun yang dimiliki oleh lembaga, seperti asuransi, bank atau institusi lain (Tarjo, 2008). Kepemilikan institusi sangat penting dalam mengawasi manajemen. Dengan kepemilikan institusi akan mendorong adanya peningkatan pengawasan. Semakin tinggi kepemilikan institusi maka akan mengurangi perilaku opportunistic manajer yang dapat mengurangi agency cost (Wahyudi \& Pawestri, 2006).

Faktor lainnya yang juga dapat berpengaruh terhadap struktur modal dan nilai perusahaan adalah pertumbuhan perusahaan (growth). Pertumbuhan (growth) perusahaan merupakan peningkatan aktivitas perusahaan pada saat sekarang dibandingkan dengan tahun sebelumnya. Pertumbuhan dimaksud berupa pertumbuhan aktiva perusahaan yang disebut dengan asset growth dan pertumbuhan penjualan yang juga disebut dengan sales growth. Meningkatnya asset dapat menambah kepercayaan kreditor terhadap perusahaan karena kreditor yakin bahwa dana yang tertanam pada perusahaan dijamin oleh besarnya asset yang dimiliki perusahaan tersebut. Asset perusahaan mempunyai peranan penting untuk membiayai operasional perusahaan oleh karenanya adanya peningkatan jumlah asset perusahaan yang digunakan untuk membiayai operasional perusahaan maka diharapkan dapat meningkatkan kemampuan perusahaan dalam menghasilkan profit bagi perusahaan. Pertumbuhan penjualan merupakan peningkatan aktivitas penjualan dari periode sebelumnya ke periode berikutnya. Pertumbuhan penjualan dapat berpengaruh pada kebijakan manajerial terhadap pendanaan operasional perusahaan yang berasal dari hutang. Dengan tingkat penjualan yang meningkat maka diharapkan juga laba akan meningkat yang selanjutnya tentu akan berdampak juga terhadap pembagian dividen oleh perusahaan sebagaimana dinyatakan oleh (Hatta, 2002) bahwa perusahaan dengan tingkat penjualan dan laba yang tinggi, akan cenderung membagikan dividen lebih konsisten dibandingkan dengan perusahaan yang tingkat pertumbuhan penjualannya rendah.

Disamping pertumbuhan perusahaan (Growth), ukuran perusahaan (Size) juga dapat mempengaruhi nilai perusahaan. Bagi manajemen jumlahassetyang besar akan memberikan keleluasaan pada pihak manajemen untuk mempergunakannya dalam upaya meningkatkan laba perusahaan. Namun dari persfektif investor jumlah asset yang besar tersebut akan menurunkan nilai perusahaan, karena jika laba yang dihasilkan tidak maksimal maka nilai return dari asset yang diinvestasikan akan semakin kecil. Pengukuran besar kecilnya perusahaan dapat dilihat dari besarnya total aset yang dimiliki perusahaan tersebut, semakin besar perusahaan maka akan semakin besar pula kebutuhan dana yang diperlukan untuk menjalankan operasionalnya.

Penelitian yang terkait dengan nilai perusahaan, dengan factor-faktor yang mempengaruhinya menunjukkan adanya inkonsistensi. Gemmill, (2001) hasil penelitiannya menyatakan bahwa struktur modal berpengaruh terhadap nilai perusahaan, hasil tersebut didukung oleh penelitian (Soliha \& Taswan, 2002) dan (Rustendi \& Jimmi, 2008). Sementara itu penelitian (Sparta, 2000) dan (Ogbulu \& Emeni, 2012) hasilnya menyatakan bahwa struktur modal tidak berpengaruh besar terhadap nilai perusahaan. Sementara itu penelitian (Kusumajaya, 2011) menyatakan bahwa pertumbuhan perusahaan berpengaruh positif dan signifikan terhadap nilai perusahaan sedangkan penelitian (Safrida, 2008) menyatakan bahwa pertumbuhan perusahaan berpengaruh negatif dan tidak signifikan terhadap nilai perusahaan. Penelian (Soliha \& Taswan, 2002), menyatakan bahwa ukuran perusahaan memiliki pengaruh positif dan signifikan terhadap nilai perusahaan, hasil tersebut didukung oleh penelitian (Suranta \& Midiastuty, 2003) dan (Pakpahan, 2010).

ROA memberikan ukuran efisiensi suatu perusahaan dalam mengelola itu aset untuk menghasilkan pendapatan. Rasio ini menunjukkan jumlah laba yang diperoleh relatif terhadap investasi dalam total aset (Fraser \& Ormiston, 2004). Rasio ini juga memberikan ukuran tingkat efektivitas manajemen suatu perusahaan yang ditunjukkan dari laba yang dihasilkan dari 
penjualan atau dari pendapatan investasi (Kasmir, 2010). ROA mencerminkan kemampuan bank manajemen dalam mengelola asetnya untuk menghasilkan laba (Dietrich \& Wanzenried, 2010). Return on Assets (ROA) dapat dipengaruhi oleh faktor turnover dari operating assets dan profit margin (Munawir, 2018).

Haneef et al., (2012) menyatakan bahwa Non-Performing Loan (NPL) merupakan indikator untuk mengukur bagaimana kemampuan bank untuk mempertahankan tingkat pinjaman kepada konsumen. Yogianta (2013) menjelaskan bahwa NPL menunjukkan rasio pinjaman bermasalah terhadap total pinjaman yang diberikan. Bank tidak hanya diminta memberikan kredit tetapi bank juga harus melakukan proses review dalam memberikan kredit. Tingkat NPL yang tinggi mencerminkan kemungkinan kerugian dan kekayaan bersih yang tinggi karena jumlah kredit macet yang tinggi dan tingkat NPL yang rendah juga mencerminkan probabilitas laba yang tinggi karena kredit macet yang rendah. (Parul, 2012) menyatakan bahwa pertumbuhan NPL melibatkan perlunya ketentuan karena mengurangi keseluruhan laba dan pemegang saham. Jika ada proporsi tinggi dalam kredit bank akan ada kemungkinan lebih tinggi bahwa bank-bank dapat menderita dari krisis keuangan dan sebaliknya

Pinasti \& Mustikawati (2018) menjelaskan bahwa Capital Adequacy Ratio (CAR) adalah rasio keuangan yang terkait dengan modal bank di mana jumlah modal bank akan mempengaruhi apakah bank dapat secara efisien menjalankan kegiatannya. Capital Adequacy Ratio merupakan rasio yang menunjukkan kecukupan modal yang ditetapkan lembaga pengatur yang khusus berlaku bagi industri-industri yang berada dibawah pengawasan pemerintah (Harahap, 2016). Sudarmawanti dan Pramono (2017) mengungkapkan bahwa peningkatan sirkulasi dan penurunan Capital Adequacy Ratio (CAR) akan menunjukkan penurunan aset bank yang masih dapat ditutupi oleh ekuitas bank yang tersedia, semakin tinggi CAR, semakin baik kondisi bank.

Loan to Deposit Ratio (LDR) merupakan rasio yang dipergunakan untuk mengetahui kemampuan bank dalam membayar kepada para penyimpan dana dengan jaminan pinjaman yang diberikan (Jumingan, 2018). Loan to Deposit Ratio merupakan rasio yang digunakan untuk mengukur komposisi jumlah kredit yang diberikan dibandingkan dengan jumlah dana masyarakat dan modal sendiri yang digunakan. Besarnya Loan to Deposit Ratio menurut peraturan pemerintah maksimum adalah $110 \%$ (Kasmir, 2012). Loan to Deposit Ratio tidak luput dari suatu faktor yang mempengaruhi tingkat perubahan rasio yang dihasilkan. Menurut (Veithzal, Sudarto, Basir, \& Rivai, 2013) ada beberapa yang mempengaruhi Loan to Deposit Ratio (LDR) yaitu: 1) kejadian yang jarang terjadi, sifatnya jangka pendek, 2) faktor musiman, 3) faktor-faktor daur usaha, dan 4) kejadian-kejadian jangka panjang.

Nilai perusahaan merupakan merupakan nilai wajar perusahaan yang menggambarkan evaluasi investor emiten tertentu sehingga nilai perusahaan adalah persepsi investor yang selalu terkait dengan harga saham (Soliha \& Taswan, 2002); (Gultom, Agustina, \& Wijaya, 2013) dan (Languju, 2016). Nilai perusahaan merupakan konsep penting bagi investor yaitu digunakan indikator pasar dalam mengevaluasi suatu perusahaan secara keseluruhan (Nurlela \& Islahudin, 2008) karena itu, nilai perusahaan diartikan sebagai harga jual perusahaan yang dianggap memadai oleh calon investor saat perusahaan akan dilikuidasi (Wahyudi \& Pawestri, 2006); (Rahmawati, 2015). Nilai perusahaan berarti cerminan dari pencapaian kinerja dalam mengoperasikan perusahaan dari pendiriannya hingga sekarang (Sundari \& Utami, 2013) dan (Sukirni, 2012). Investor yang mengevaluasi bahwa suatu perusahaan memiliki prospek yang baik di masa depan cenderung membeli saham perusahaan. Akibatnya, permintaan tinggi untuk saham menyebabkan harga saham menjadi lebih tinggi karena investor memberikan nilai tinggi kepada perusahaan (Zuhroh, 2019)).

Struktur modal, menurut Margaritis dan Psillaki (2010) mengacu pada campuran utang dan modal ekuitas yang dikelola oleh perusahaan dengan berbagai sumber dana, terutama untuk dana/modal jangka panjang. Bagi mereka, ini adalah kerangka kerja, yang menunjukkan 
bagaimana ekuitas dan utang digunakan untuk operasi perusahaan pembiayaan. Mereka berpendapat bahwa penting untuk menemukan struktur modal yang optimal atau kombinasi optimal hutang dan ekuitas karena struktur modal memaksimalkan nilai perusahaan. Oleh karena itu mereka mengklaim bahwa, tujuan utama struktur modal adalah untuk mengetahui campuran utang dan ekuitas yang optimal. Struktur modal yang optimal dapat diartikan sebagai struktur modal yang dapat meminimalkan biaya penggunaan modal sehingga akan memaksimalkan nilai perusahaan (Harjito \& Martono, 2008). Struktur modal juga dapat diartikan sebagai perimbangan atau perbandingan antara jumlah hutang jangka panjang dengan modal sendiri (Riyanto, 2013). Struktur modal yang optimal yaitu struktur modal yang dapat meminimumkan biaya modal ratarata dan memaksimumkan nilai perusahaan (Riyanto, 2013).

Kusumawati, Topowijono, \& Endang (2016) mengatakan, profitabilitas merupakan kemampuan perusahaan untuk menghasilkan laba pada masa mendatang dan merupakan indikator dari keberhasilan operasi perusahaan. Profitabilitas perusahaan mempengaruhi besaran struktur modal perusahaan. karena semakin besar keuntungan perusahaan maka semakin besar laba ditahan yang dapat digunakan dalam operasionalnya. Perusahaan yang mempunyai profit tinggi, akan menggunakan hutang dalam jumlah rendah, dan sebaliknya bila profit rendah maka penggunakan utang semakin tinggi sebagaimana dinyatakan (Brigham \& Houston, 2010), bahwa perusahaan dengan tingkat pengembalian yang tinggi atas investasi menggunakan hutang yang relatif kecil.Hal ini disebabkan dengan return on assets yang tinggi tersebut, memungkinkan bagi perusahaan melakukan permodalan dengan laba ditahan saja.

Kepemilikan institusi adalah proporsi kepemilikan saham pada akhir tahun yang dimiliki oleh lembaga, seperti asuransi, bank atau institusi lain (Tarjo, 2008). Menurut Struktur kepemilikan (Ismiyanti \& Hanafi, 2004) semakin tinggi kepemilikan institusi maka akan semakin meningkatkan pengawasan eksternal terhadap perusahaan. Dengan adanya pengawasan pihak eksternal maka jalannya perusahaan dapat lebih diawasi. Selain itu (Wahyudi \& Pawestri, 2006) menyatakan pentingnya kepemilikian institusi dalam memonitor manajemen, hal ini berarti bahwa kepemilikan institusi akan mendorong peningkatan pengawasan, semakin tinggi kepemilikan institusi maka akan mengurangi perilaku opportunistic manajer yang dapat mengurangi agency cost. Kepemilikan oleh institusi adalah proporsi kepemilikan saham perusahaan yang dimiliki oleh institusi atau lembaga seperti perusahaan asuransi, bank, perusahaan investasi dan kepemilikan institusi lain (Tarjo, 2008).

Pertumbuhan perusahaan adalah kemampuan perusahaan untuk mempertahankan posisi bisnisnya dalam perkembangan ekonomi dan industri tempat ia beroperasi (Hartanty, 2013). Bagi investor, prospek perusahaan yang memiliki potensi tumbuh tinggi memberikan keuntungan karena investasi yang ditanamkan diharapkan dapat memberikan return yang tinggi di masa yang akan datang. Perusahaan yang tumbuh pesat cenderung mampu membagikan dividen yang lebih tinggi (Weston \& Brigham, 2005). Pertumbuhan dimaksud berupa assset growth (pertumbuhan aktiva) dan sales growth (pertumbuhan penjualan). Asset yang merupakan aktiva untuk operasional perusahaan diasumsikan bahwa semakin besar asset maka semakin besar hasil operasional yang diperoleh perusahaan. Begitu juga dengan pertumbuhan penjualan, perusahaan dengan tingkat penjualan dan laba yang tinggi maka ada kecenderungan perusahaan akan membagikan dividen lebih konsisten dibandingkan dengan perusahaan yang tingkat pertumbuhan penjualannya rendah (Hatta, 2002).

Pertumbuhan aset adalah peluang pertumbuhan bagi perusahaan di masa depan (Mai, 2006). Pertumbuhan Aset menurut (Prasetyo, 2011) didefinisikan sebagai pertumbuhan perusahaan yang selalu identik dengan aset perusahaan (baik aset fisik seperti tanah, bangunan, bangunan dan aset keuangan seperti uang tunai, piutang, dan lain-lain). Paradigma aset sebagai indikator pertumbuhan perusahaan banyak digunakan. Nilai total aset dalam neraca menentukan kekayaan perusahaan. Pertumbuhan adalah dinyatakan sebagai total pertumbuhan aset di mana 
pertumbuhan aset masa lalu akan mencerminkan profitabilitas dan pertumbuhan yang datang (Taswan, 2003). Pertumbuhan dapat berupa kenaikan atau penurunan total aset yang dialami oleh perusahaan dalam jangka waktu tertentu. Pertumbuhan aset dihitung sebagai perubahan persentase aset pada waktu tertentu terhadap tahun sebelumnya (Saidi, 2004). Asset yang merupakan aktiva untuk operasional perusahaan diasumsikan bahwa semakin besar asset maka semakin besar hasil operasional yang diperoleh perusahaan. Perusahaan yang memiliki aktiva sebagai agunan hutang cenderung akan menggunakan hutang dalam jumlah yang lebih besar, (Weston \& Brigham, 2005), Aktiva yang dimaksud sebagai jaminan atas hutang adalah aktiva tetap (fixed assets). Perusahaan yang bertumbuh pesat cenderung lebih banyak menggunakan utang dari pada perusahaan yang bertumbuh secara lambat (Weston \& Brigham, 2005).

Pertumbuhan penjualan merupakan meningkatnya nilai penjualan tahun sesudahnya (tahun ke t) dibandingkan dengan tahun sebelumnya (tahun ke t-1) Menurut (Weston \& Copeland, 2010) pertumbuhan penjualan merupakan variabel yang mempengaruhi struktur modal. Pertumbuhan penjualan yang meningkat dapat menaikkan kepercayaan kreditor dalam pemenuhan kebutuhan pendanaan external. Disamping itu perusahaan dengan tingkat penjualan yang relative stabil akan mendapat kepercayaan dalam memperoleh hutang/pinjaman dari pihak kreditur meskipun berdampak pada biaya tetap berupa bunga pinjamanan. Sebagaimana dinyatakan (Brigham \& Houston, 2011) bahwa perusahaan dengan penjualan yang relatif stabil dapat lebih aman memperoleh lebih banyak pinjaman dan menanggung beban tetap yang lebih tinggi dibandingkan dengan perusahaan yang penjualannya tidak stabil.

Menurut (Atmaja, 2008) ukuran perusahaan adalah skala yang mengklasifikasikan ukuran perusahaan menggunakan berbagai mode: total aset, ukuran log, nilai pasar saham, total penjualan dan sejenisnya. Lebih tinggi total aset dan penjualan perusahaan menunjukkan pergantian dana di perusahaan. Semakin tinggi total aset, semakin besar modal yang diinvestasikan perusahaan. Atas dasar deskripsi, itu dapat dinyatakan bahwa ukuran perusahaan adalah jumlah aset yang dimiliki perusahaan. Ukuran perusahaan dapat dihitung dengan logaritma natural dari total aktiva (Brigham \& Houston, 2010). Beberapa penelitian terdahulu menjelaskan bahwa ukuran perusahaan memiliki pengaruh terhadap besaran struktur modal perusahaan. Hasil penelitian (Moh'd, Perry, \& Rimbey, 1998) menunjukkan bahwa perubahan struktur aktiva berpengaruh negatif terhadap perubahan struktur modal yang dilakukan oleh manajer.

\section{Pengembangan Hipotesis}

Setiap perusahaan berekspektasi profit dalam usahanya, kemampuan menghasilkan laba (profitabilitas) akan menjadi factor penting dalam pendanaan perusahaan.Profitabilitas berpengaruh terhadap struktur modal, semakin tinggi keuntungan suatu perusahaan maka akan semakin menurun hutangnya karena semakin banyak dana internal yang tersedia untuk mendanai investasinya (Brigham \& Houston, 2010). Lebih lanjut (Brigham \& Houston, 2010) menyatakan bahwa perusahaan dengan tingkat pengembalian yang tinggi atas investasi menggunakan hutang yang relatif kecil. Tingkat pengembalian yang tinggi memungkinkan untuk membiayai sebagian besar kebutuhan pendanaan dengan dana yang dihasilkan secara internal. Semakin besar tingkat profitabilitas maka akan semakin kecil rasio struktur modal. Oleh karenanya profitabilitas berpengaruh negative terhadap struktur modal. Kepemilikan institusi memiliki arti penting dalam mengawasi manajemen, karena dengan kepemilikan institusi akan mendorong peningkatan pengawasan yang lebih optimal, semakin tinggi kepemilikan institusi maka akan mengurangi perilaku opportunistic manajer yang dapat mengurangi agency cost (Wahyudi \& Pawestri, 2006).

Ukuran perusahaan adalah ukuran atau jumlah aset dimiliki oleh perusahaan. Perusahaan yang pertumbuhan penjualan yang tinggi membutuhkan sumber daya perusahaan yang besar 
dukung. Pada gilirannya, perusahaan dengan penjualan rendah tingkat pertumbuhan, kebutuhan sumber daya perusahaan juga lebih kecil. Ukuran perusahaan akan mempengaruhi modal struktur (Zuhria \& Riharjo, 2016). Berdasarkan Sudiyatno dan Sari (2013), perusahaan besar bisa mengarah pada hutang yang lebih tinggi karena semakin besar perusahaan, kebutuhan dana juga semakin besar, yang bisa berasal dari dana eksternal, yaitu utang. Besar perusahaan memiliki kualitas dan kegiatan khusus yang dikenal oleh publik dibandingkan dengan yang kecil perusahaan, sehingga kebutuhan hutang perusahaan besar akan lebih tinggi daripada perusahaan kecil.

Penelitian empiris oleh (Krishnan \& Moyer, 1996), (Bhadhuri, 2002) dan (Moh'd et al., 1998) menunjukkan bahwa pertumbuhan penjualan (growth of sales) merupakan salah satu variabel yang berpengaruh terhadap struktur modal perusahaan. Semakin tinggi struktur aktiva maka semakin besar aktiva tetap yang dapat dijadikan agunan hutang oleh perusahaan tersebut. Sebaliknya, semakin rendah struktur aktiva dari suatu perusahaan, maka akan semakin rendah kemampuan dari perusahaan tersebut untuk dapat menjamin hutang jangka panjangnya. Penelitian lainnya (Ozkan, 2001) juga menemukan bahwa jumlah utang yang dibiayai oleh perusahaan berbanding terbalik dengan pertumbuhan perusahaan. Hasil penelitian tersebut juga konsisten dengan hasil penelitian oleh (Bhadhuri, 2002) yaitu pertumbuhan perusahaan mempunyai pengaruh negatif terhadap struktur modal. Growth opportunity adalah peluang pertumbuhan suatu perusahaan di masa depan (Mai, 2006). Dengan demikian maka growth opportunity berpengaruh positif terhadap sruktur modal, (Setiawan, 2006).

Profitabilitas merupakan kemampuan suatu perusahaan dalam menghasilkan keuntungan dan mengukur tingkat efisiensi operasional dan penggunaan harta yang dimilikinya (Chen, 2004). Kemampuan dimaksud tentunya akan menjadi salah satu factor yang dipertimbangkan dalampenilaian perusahaan. Perusahaan yang memiliki profitabilitas besar tiap tahunnya cenderung diminati oleh investor. Para investor ini menganggap perusahaan yang profitnya besar akan menghasilkan return yang besar. Para investor dan calon investor akan menilai perusahaan secara positif apabila ratio profitabilitas menunjukkan trend positif, yang menunjukkan prospek perusahaan yang semakin baik dan akan ditangkap oleh investor sebagai sinyal positif dari perusahaan. Kenaikkan permintaan sahamsuatu perusahaan secara tidak langsung akan menaikkan harga saham di pasarmodal. Hasil penelitian (Septiono, Suhadak, \& Darminto, 2013) menyatakan bahwa profitabilitas signifikan pengaruhnya dan hubungannya positif terhadap variabel nilai perusahaan

Kepemilikan institusi adalah proporsi kepemilikan saham pada akhir tahun yang dimiliki oleh lembaga, seperti asuransi, bank atau institusi lain (Tarjo, 2008). Kepemilikan institusi memiliki arti penting dalam memonitor manajemen. Dengan kepemilikan institusi diyakini mampu memonitor manajemen dalam pengambilan keputusan keuangan. Ukuran perusahaan atau Firm size adalah ukuran yang menggambarkan besar kecilnya perusahaan yang ditunjukkan dengan besar kecilnya aktiva, jumlah penjualan, rata-rata tingkat penjualan, dan rata-rata total aktiva (Ferri \& Jones, 1979). Ukuran perusahaan dianggap mampu mempengaruhi nilai perusahaan, karena semakin besar ukuran perusahaan akan menambah kepercayaan investor untuk melakukan investasi dalam bentuk pembelian saham yang pada akhirnya akan mampu meningkatkan nilai perusahaan. Hasil penelitian (Soliha \& Taswan, 2002); dan (Taswan, 2003) menyimpulkan bahwa ukuran perusahaan memiliki pengaruh terhadap nilai perusahaan.

Faktor lainnya yang juga dapat berpengaruh terhadap nilai perusahaan adalah pertumbuhan perusahaan (growth). Pertumbuhan perusahaan adalah salah satu tujuan yang diharapkan oleh pihak internal dan eksternal perusahaan karena akan membawa pengaruh baik bagi perusahaan dan pihak-pihak yang memiliki minat pada perusahaan seperti investor, kreditor dan pemegang saham. Pertumbuhan perusahaan adalah dampak dari dana perusahaan atau aliran keuangan dari perubahan operasional yang disebabkan oleh pertumbuhan atau penurunan 
volume bisnis (Helfert, 1997). Asset perusahaan mempunyai peranan penting untuk membiayai operasional perusahaan oleh karenanya adanya peningkatan jumlah asset perusahaan yang digunakan untuk membiayai operasional perusahaan maka diharapkan dapat meningkatkan kemampuan perusahaan dalam menghasilkan profit bagi perusahaan. Dalam upaya menghasilkan return yang maksimal, perusahaan membutuhkan pendanaan yang memadai untuk mendukung operasionalnya. Besarnya struktur modal merupakan hal penting yang harus diperhatikan oleh perusahaan kerena baik buruknya struktur modal akan mempunyai efek langsung terhadap posisi finansial perusahaan yang pada akhirnya akan mempengaruhi nilai perusahaan. Oleh karena itu dalam pemanfaatannya harus efisien sehingga dapat menjadikannya lebih optimal. Struktur modal diyakini mampu menjadi perantara dari profitabilitas, kepemilikan sahan, ukuran perusahaan dan pertumbuhan perusahaan dengan nilai perusahaan.

Berdasarkan pengembangan hipotesis di atas, maka hipotesis penelitian ini adalah:

H1 : Profitabilitas, kepemilikan institusi, pertumbuhan perusahaan dan ukuran perusahaan berpengaruh signifikan terhadap struktur modal.

H2 : Profitabilitas, kepemilikan institusi, ukuran perusahaan, dan pertumbuhan perusahaan dan struktur modal berpengaruh signifikan terhadap nilai perusahaan.

\section{METODE}

Populasi dalam penelitian ini adalah perusahaan sektor industri Pariwisata yang terdaftar di Bursa Efek Indonesia periode tahun 2013-2018 yang memiliki laporan keuangan lengkap dan dipublikasikan dalam Indonesian Capital Market Directory (ICMD) yang berjumlah 20 perusahaan yang terdaftar di BEI. Sampling yang diambil adalah perusahaan sektor industri kepariwisataan yang terdaftar di Bursa Efek Indonesia yang terdaftar sampai dengan awal tahun 2018. Keseluruhan populasi dijadikan sample (Total Sampling). Pemilihan sampel dilakukan dengan memperhatikan kreteria sampel sebagai berikut:

1. Perusahaan yang terdaftar di Bursa Efek Indonesia adalah perusahaan yang tergolong dalam katagori sektor industri kepariwisataan (Hospitality Industry) yang terdiri dari hotel, restoran dan kepariwisataan.

2. Perusahaan yang sahamnya tetap beredar sampai Desember 2018, serta mempublikasikan laporan keuangan secara rutin.

3. Perusahaan tidak pernah mengalami delisting dari Bursa Efek Indonesia sehingga bisa terus menerus melakukan perdagangan saham di BEI selama periode estimasi.

Prosedur pengumpulan data dalam penelitian ini adalah dengan mengumpulkan data laporan keuangan (annual report) yang sudah diaudit (audited) yang diterbitkan oleh Indonesia Capital Market Directory (ICMD) untuk perusahaan yang bergerak disektor industri kepariwisataan yang terdaftar di Bursa Efef Indonesia. Data dikumpulkan berdasarkan dimensi waktu dan urutan waktu dan bersifat cross sectional dan time series atau disebut juga data panel. Penggunaan path analysis ini adalah untuk mengetahui pengaruh dari variabel-variabel eksogen terhadap variabel-variabel endogen.

\section{HASIL DAN PEMBAHASAN}

Uji asumsi klasik merupakan persyaratan dalam pengujian statistik parametrik dengan teknik analisis regresi linier berganda. Dari hasil pengolahan data diperoleh gambar sebagaimana dapat dilihat pada gambar 1 sebagai berikut : 


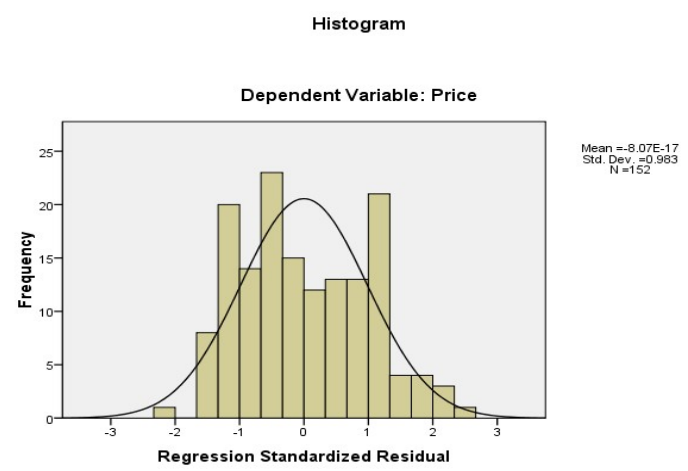

Gambar. 1. Grafik histogram variabel dependen Price

Gambar 1, terlihat bahwa variabel dependen Price pada model II menunjukkan bahwa normalitas data sudah normal dan grafiknya sudah tidak melenceng serta tidak terdapat data yang outlier.

Berikutnya hasil pengolahan data diperoleh hasil sebagaimana dapat dilihat pada Tabel 1 sebagai berikut :

Tabel 1. Hasil pengujian multikolineritas

\begin{tabular}{|c|c|c|c|c|}
\hline & \multirow{2}{*}{ Model } & \multicolumn{2}{|c|}{ Collinearity Statistics } & \multirow{2}{*}{ Keterangan } \\
\hline & & Tolerance & VIF & \\
\hline \multirow{6}{*}{1} & (Constant) & & & \\
\hline & Return On Equity & .918 & 1.194 & Tidak terjadi multikolonieritas \\
\hline & Kep. Institusional & .888 & 1.243 & Tidak terjadi multikolonieritas \\
\hline & Growth Asset & .945 & 1.089 & Tidak terjadi multikolonieritas \\
\hline & Firm Size & .878 & 1.213 & Tidak terjadi multikolonieritas \\
\hline & Dedt Asset Ratio & .834 & 1.214 & Tidak terjadi multikolonieritas \\
\hline
\end{tabular}

Tabel 2, dapat dilihat bahwa seluruh variabel independent memiliki nilai tolerance lebih besar dari 0,1 dan nilai VIF memiliki nilai lebih kecil dari 10.

Kemudian hasil pengolahan data statistik diperoleh bahwa grafik Scatterplot antara SRESID dan ZPRED. Untuk model penelitian terdapat pada gambar 2 berikut :

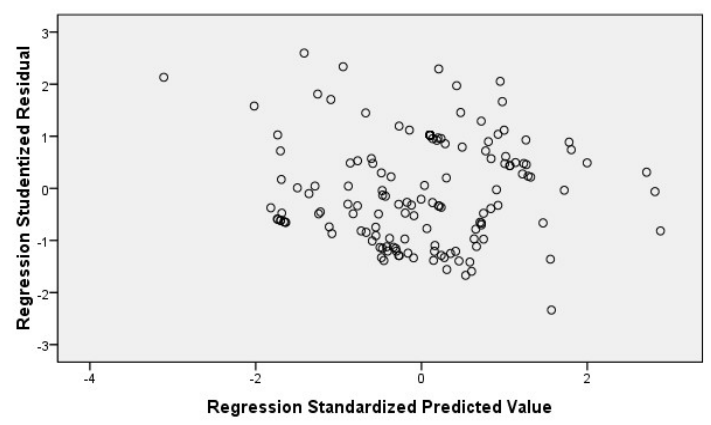

Gambar 2. Uji Heterokedastisitas Model II

Gambar 2 tersebut di atas maka data penelitian yang diolah dinyatakan terbebas dari heterokedastisitas.

Korelasi antar variabel exogenous menggambarkan seberapa besar hubungan antar variabel bebas (exogenous). Besarnya korelasi antar variabel bebas tersebut secara statistik dapat dilihat pada tabel 2 sebagai berikut : 
Tabel 2. Korelasi antar variabel Exogenous

\begin{tabular}{|c|c|c|c|c|c|}
\hline & & $\begin{array}{l}\text { Retrun On } \\
\text { Equity }\end{array}$ & $\begin{array}{c}\text { Ukuran } \\
\text { perusahaan }\end{array}$ & Growt Assets & Firm Size \\
\hline \multirow{3}{*}{$\begin{array}{l}\text { Retrun On } \\
\text { Equity }\end{array}$} & Pearson Correlation & 1 & -.020 & .165 & .118 \\
\hline & Sig. (2-tailed) & & .916 & .079 & .147 \\
\hline & $\mathrm{N}$ & 154 & 154 & 154 & 154 \\
\hline \multirow{3}{*}{$\begin{array}{l}\text { Ukuran } \\
\text { perusahaan }\end{array}$} & Pearson Correlation & -.010 & 1 & -.010 & .158 \\
\hline & Sig. (2-tailed) & .838 & & .899 & .060 \\
\hline & $\mathrm{N}$ & 154 & 154 & 154 & 154 \\
\hline \multirow[t]{3}{*}{ Growt Assets } & Pearson Correlation & .148 & -.010 & 1 & .138 \\
\hline & Sig. (2-tailed) & .069 & .899 & & .090 \\
\hline & $\mathrm{N}$ & 154 & 154 & 154 & 154 \\
\hline \multirow[t]{5}{*}{ Firm Size } & Pearson Correlation & .118 & $.169^{\circ}$ & .137 & 1 \\
\hline & Sig. (2-tailed) & .147 & .058 & .080 & \\
\hline & $\mathrm{N}$ & 154 & 154 & 154 & 154 \\
\hline & Sig. (2-tailed) & .000 & .000 & .172 & .250 \\
\hline & $\mathrm{N}$ & 154 & 154 & 154 & 154 \\
\hline \multicolumn{6}{|c|}{ *. Correlation is significant at the 0.05 level (2-tailed). } \\
\hline \multicolumn{6}{|c|}{ **. Correlation is significant at the 0.01 level (2-tailed). } \\
\hline
\end{tabular}

Dari tabel tersebut dapat dijelaskan bahwa korelasi antar variabel sebagai berikut :

a. Hubungan antara ROE dengan KIS sebesar -0,020 dengan tigkat signifikansi 0.916 (tidak signifikan)

b. Hubungan antara ROE dengan GA sebesar 0,148 dengan tigkat signifikansi 0.79 (tidak signifikan)

c. Hubungan antara ROE dengan SIZE sebesar 0,118 dengan tigkat signifikansi 0.147 (tidak signifikan)

d. Hubungan antara KIS dengan GA sebesar -0,010 dengan tigkat signifikansi 0.838 (tidak signifikan)

e. Hubungan antara KIS dengan SIZE sebesar 0,169 dengan tigkat signifikansi 0.058 (tidak signifikan)

f. Hubungan antara GA dengan SIZE sebesar 0,137 dengan tigkat signifikansi 0.080 (tidak signifikan)

Dengan demikian dapat dinyatakan bahwa antara variabel exogenous tidak saling berkorelasi. Secara keseluruhan variabel penelitian dengan diagram jalur persamaan strukturalnya dapat digambarkan sebagai berikut: 


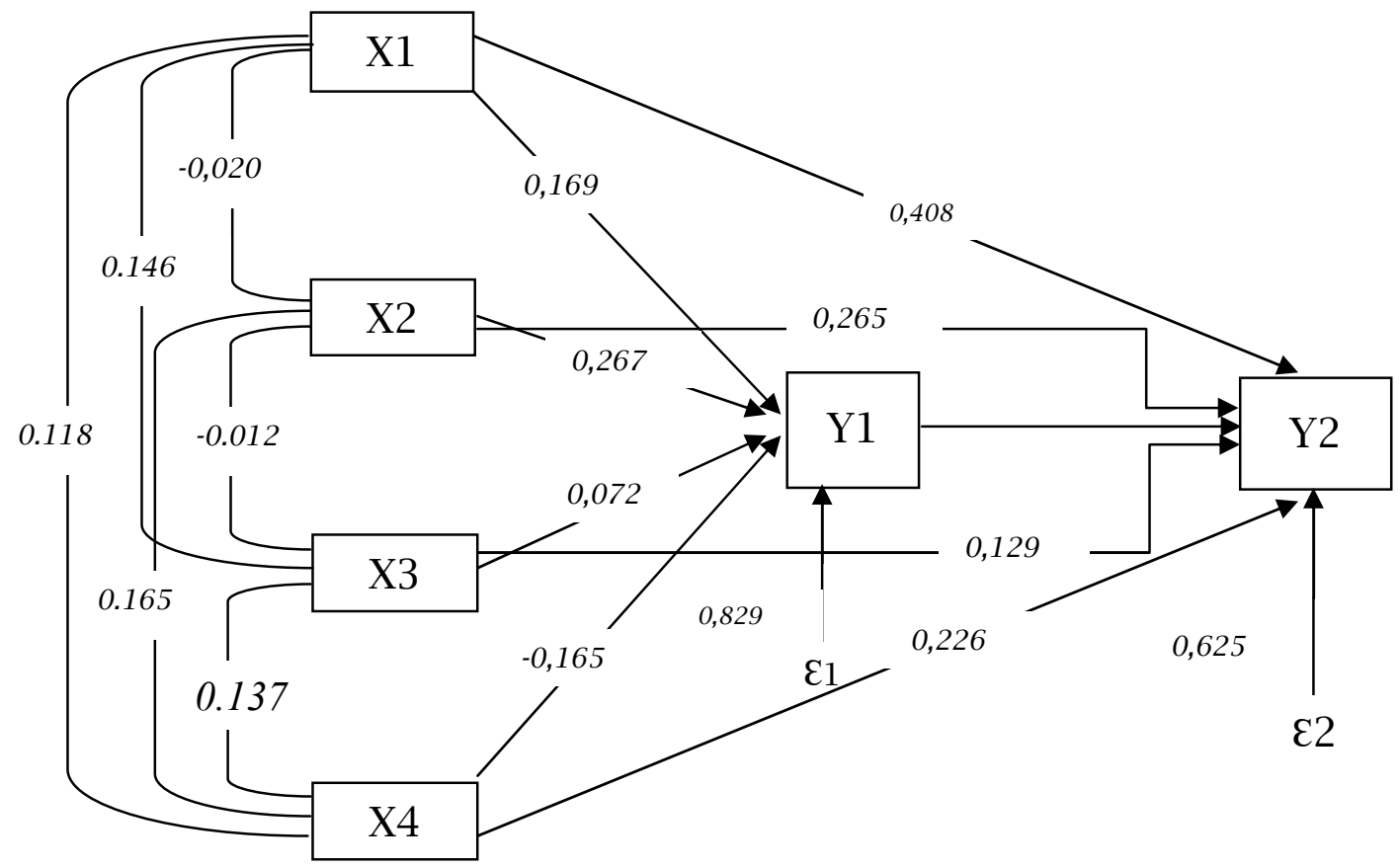

Gambar 3. Model Persamaan Analisis Jalur

\section{Pengaruh Ukuran Perusahaan, Kepemilikan Institusi, Ukuran Perusahaan Dan Ukuran Perusahaan Terhadap Struktur Modal}

Hasil persamaan regresi I menunjukkan bahwa profitabilitas yang diproksikan dengan Return On Equity (ROE) dan Kepemilikan institusi (KIS) adalah searah atau positif signifikan dengan struktur modal yang diproksikan dengan Debt Asset Ratio (DAR) dimana setiap kenaikan ROE, KIS diikuti oleh kenaikan DAR. Sedangkan Pertumbuhan perusahaan yang diproksikan dengan Growth Assets (GA) juga searah atau positif tetapi tidak signifikan dengan struktur modal yang diproksikan dengan Debt Asset Ratio (DAR). Sebaliknya SIZE memiliki hubungan yang negative signifikan terhadap struktur modal (DAR) dimana setiap kenaikan Firm Size (SIZE) diikuti oleh penurunan struktur modal (DAR).

Hipotesis 1 penelitian ini menyatakan bahwa profitabilitas, kepemilikan institusi, pertumbuhan perusahaan dan ukuran perusahaan berpengaruh signifikan terhadap struktur modal. Hasil pengujian secara simultan (Uji F) dengan membandingkan Fhitung dengan Ftabel diperoleh hasil bahwa Fhitung $>$ Ftabeldimana Fhitung 7,567 dan Ftabel 2,43 dengan demikian maka Ho ditolak dan Ha diterima. Begitu juga dengan hasil perbandingan sig. uji $\mathrm{F}$ dengan dengan tingkat signifikansi $\alpha=0.05$ atau $5 \%$ diperoleh hasil sig. hasil uji $\mathrm{F}<\alpha=0.05$ dimana sig uji F 0,000 dan $\alpha=0.05$ dengan demikian maka Ho ditolak dan Ha diterima. Dari hasil uji $\mathrm{F}$ tersebut disimpulkan bahwa secara simultan profitabilitas, kepemilikan institusi, pertumbuhan perusahaan dan ukuran perusahaan berpengaruh signifikan terhadap Struktur Modal.

Pengujian secara parsial menunjukan bahwa variabel profitabilitas (ROE) mempunyai nilai thitung 2,887 yang lebih besar dari ttabel 1,976 dan tingkat signifikansi sebesar 0,004 yang lebih kecil dari $\alpha=0,05$ dengan demikian maka Ho ditolak, Ha diterima. Sehingga dapat disimpulkan bahwa variabel profitabilitas (ROE) berpengaruh positif signifikan terhadap struktur modal (DAR) pada perusahaan sektor industri kepariwisataan yang terdaftar di BEI tahun 20132018. Hasil penelitian ini bertentangan dengan pendapat Brigham \& Houston (2010) yang menyatakan bahwa perusahaan dengan tingkat pengembalian yang tinggi atas investasi akan menggunakan hutang yang relatif kecil. Tingkat pengembalian yang tinggi memungkinkan untuk membiayai sebagian besar kebutuhan pendanaan dengan dana yang dihasilkan secara internal. 
Semakin besar tingkat profitabilitas maka akan semakin kecil rasio struktur modal. Hasil penelitian ini juga tidak sejalan dengan penelitian oleh (Krishnan \& Moyer, 1996) dan (Bhadhuri, 2002) yang menyatakan profitabilitas berpengaruh negatif signifikan terhadap struktur modal. Namun didukung atau sejalan dengan penelitian (Prabansari \& Kusuma, 2005) yang menyatakan bahwa profitabilitas berpengaruh positif secara signifikan terhadap struktur modal. Hal tersebut disebabkan perusahaan sektor industri kepariwisataan pada kurun waktu 2007-2014 cenderung melakukan pengembangan usaha dengan pembiayaan modal asing dari pada modal sendiri karena sumber pendanaan internal khususnya laba ditahan kurang memadai sehingga sumber pendanaan lebih banyak dari modal asing hal ini terlihat dari pertumbuhan modal asing lebih besar dari pertumbuhan modal sendiri.

Variabel Kepemilikan institusi (KIS) mempunyai nilai thitung 4,008 yang lebih besar dari ttabel 1,976 dan tingkat signifikansi sebesar 0,000 yang lebih kecil dari $\alpha=0,05$ dengan demikian maka Ho ditolak, Ha diterima. Sehingga dapat disimpulkan bahwa variabel Kepemilikan institusi (KIS) berpengaruh positif signifikan terhadap struktur modal (DAR) pada perusahaan sektor industri kepariwisataan yang terdaftar di BEI tahun 2013-2018. Hasil penelitian ini sejalan dengan agency theory, (Jensen \& Meckling, 1976) yang menyatakan bahwa adanya pemisahan yang jelas antara fungsi kepemilikan dengan fungsi pengelolaan. Semakin meningkat kepemilikan institusi diharapkan semakin kuat kontrol terhadap manajemen. Bila biaya monitoring tersebut tinggi maka perusahaan akan menggunakan pihak ketiga yaitu kreditor untuk membantu melakukan pengawasan. Namun hasil penelitian ini tidak sejalan dengan hasil penelitian (Subiyantoro \& Andreani, 2003) menyatakan bahwa variabel kepemilikan institusi mempunyai pengaruh negatif dan signifikan terhadap leverage.

Variabel Pertumbuhan perusahaan (GA) mempunyai nilai thitung 1.005 yang lebih kecil dari ttabel 1.976 dan tingkat signifikansi sebesar 0,316 yang lebih besar dari $\alpha=0,05$ dengan demikian maka Ho diterima dan Ha ditolak. Sehingga dapat ditarik kesimpulkan bahwa variabel Pertumbuhan perusahaan (GA) berpengaruh positif tidak signifikan terhadap struktur modal (DAR) pada perusahaan sektor industri kepariwisataan yang terdaftar di BEI tahun 2013-2018. Hasil penelitian ini berbeda dengan pendapat (Weston \& Brigham, 2005) yang menyatakan bahwa perusahaan dengan tingkat pertumbuhan yang tinggi akan lebih banyak mengandalkan pada modal eksternal. Variabel ukuran perusahaan (Size) mempunyai nilai thitung -3.269 yang lebih kecil dari ttabel 1.976 dan tingkat signifikansi sebesar 0,001 yang lebih kecil dari $\alpha=0,05$ dengan demikian maka Ho ditolak, Ha diterima. Sehingga dapat disimpulkan bahwa variabel ukuran perusahaan (Size) berpengaruh negatif signifikan terhadap struktur modal (DAR) pada perusahaan sektor industri kepariwisataan yang terdaftar di BEI tahun 2013-2018. Hasil penelitian ini tidak sejalan dengan penelitian (Prabansari \& Kusuma, 2005) dan (Setiawan, 2006) yang menyatakan bahwa Ukuran perusahaan berpengaruh positif signifikan terhadap struktur modal.

\section{Pengaruh Profitabiltas, Kepemilikan Institusi, Pertumbuhan Perusahaan, Ukuran Perusahaan Dan Struktur Modal Terhadap Nilai Perusahaan.}

Hasil persamaan regresi II menunjukkan bahwa Profitabiitas yang diproksikan dengan Return On Equity, Kepemilikan institusi, Pertumbuhan perusahaan yang diproksikan dengan Growth Assets, dan struktur modal yang diproksikan dengan DAR adalah searah atau positif dengan nilai perusahaan (PRICE) dimana setiap kenaikan ROE, KIS, GA dan DAR diikuti oleh kenaikan nilai perusahaan (PRICE). Sebaliknya Firm Size (SIZE) memiliki hubungan yang negative terhadap nilai perusahaan (PRICE) dimana setiap kenaikan Firm Size (SIZE) akan diikuti oleh penurunan nilai perusahaan (PRICE)

atau $\mathrm{Y}_{2}=-92,018 \mathrm{a}+11,263 \mathrm{ROE}+5,815 \mathrm{KIS}+0,717 \mathrm{GA}-0,875 \mathrm{SIZE}$ 
Hasil pengujian hipotesis memberikan gambaran tentang variabel yang mempunyai pengaruh terbesar terhadap Nilai Perusahaan, yaitu Struktur Modal (DAR) sebesar 49,68\% dan pengaruh total terkecil yaitu pengaruh pertumbuhan penjualan terhadap harga saham sebesar $12 \%$.

Hasil pengujian Uji F terhadap Hipotesis II dengan membandingkan Fhitung dengan Ftabel diperoleh bahwa Fhitung > Ftabel dimana Fhitung11,181 sedangkan Ftabel sebesar 2,28 dengan demikian maka Ho ditolak dan Ha diterima, begitu juga perbandingan sig. Uji $\mathrm{F}$ dengan sig. $\alpha=0,05$ diperoleh hasil bahwa nilai signifikansinya sebesar 0,000 yang berarti lebih kecil dari sig. $\alpha=0,05$ dengan demikian maka Ho ditolak dan Ha diterima. Sehingga dapat ditarik kesimpulan bahwa ada pengaruh yang signifikan antara Profitabilitas, KIS, Pertumbuhan perusahaan dan Size terhadap Nilai Perusahaan melalui Struktur Modal.

Pengujian secara parsial dengan menggunakan Uji t pada variabel Profitabilitas (ROE) mempunyai nilai thitung $=5,671$ yang lebih besar dari tabel $=1.976$ dan tingkat signifikansi thitung sebesar 0,000 yang lebih kecil dari $\alpha=0,05$ dengan demikian maka Ho ditolak Ha diterima. Sehingga dapat ditarik kesimpulan bahwa variabel Ukuran perusahaan (ROE) berpengaruh signifikan terhadap Nilai Perusahaan (PRICE) pada perusahaan sektor industri kepariwisataan yang terdaftar di BEI tahun 2013-2018. Hasil ini sesuai dengan (Sparta, 2000); (Pakpahan, 2010), (Septiono et al., 2013) yang menyatakan bahwa profitabilitas berpengaruh signifikan pengaruhnya dan hubungannya positif terhadap variabel nilai perusahaan. Namun berbeda dengan hasil penelitian (Suharli, 2006) dan (Indriyatni, 2012) yang menyatakan profitabilitas berpengaruh tidak signifikan terhadap nilai perusahaan.

Selanjutnya untuk variabel Kepemilikan institusi (KIS) dengan nilai thitung 4.008 yang lebih besar dari ttabel 1.976 dan tingkat signifikansi thitung sebesar 0,000 yang lebih kecil dari $\alpha$ $=0,05$ dengan demikian maka Ho ditolak Ha diterima. Sehingga dapat disimpulkan bahwa variabel Kepemilikan institusi (KIS) berpengaruh signifikan terhadap Nilai Perusahaan (PRICE) pada perusahaan sektor industri kepariwisataan yang terdaftar di BEI tahun 2013-2018. Kepemilikan instutusional berpengaruh pada nilai perusahaan, Semakin besar kepemilikan oleh institusi keuangan maka semakin besar pula kekuatan suara dan dorongan untuk mengoptimalkan nilai perusahaan Dengan kepemilikan institusi diyakini mampu memonitor manajemen dalam pengambilan keputusan keuangan.

Berikutnya untuk variabel Pertumbuhan perusahaan (GA) dengan nilai thitung 1.005 yang lebih kecil dari ttabel 1.976 dan tingkat signifikansi thitung sebesar 0,316 yang lebih besar dari $\alpha=0,05$ dengan demikian maka Ho diterima dan Ha ditolak. Sehingga dapat disimpulkan bahwa variabel Ukuran perusahaan (GA) berpengaruh tidak signifikan terhadap Nilai Perusahaan (PRICE) pada perusahaan sektor industri kepariwisataan yang terdaftar di BEI tahun 2013-2018. tidak sejalan dengan penelitian (Prabansari \& Kusuma, 2005) yang menyatakan pertumbuhan perusahaan berpengaruh positif dan signifikan terhadap nilai perusahaan.

Variabel ukuran perusahaan (Size) mempunyai nilai thitung -3.269 yang lebih kecil dari ttabel 1.976 dan tingkat signifikansi thitung sebesar 0,001 yang lebih kecil dari $\alpha=0,05$ dengan demikian maka Ho diterima, Ha ditolak. Sehingga dapat disimpulkan bahwa variabel ukuran perusahaan (Size) berpengaruh signifikan terhadap struktur modal (DAR) pada perusahaan sektor industri kepariwisataan yang terdaftar di BEI tahun 2013-2018. Ukuran perusahaan dianggap mampu mempengaruhi nilai perusahaan, karena semakin besar ukuran perusahaan akan menambah kepercayaan investor untuk melakukan investasi dalam bentuk pembelian saham yang pada gilirannya akan meningkatkan nilai perusahaan, (Soliha \& Taswan, 2002), Hasil penelitian ini didukung oleh hasil penelitian (Soliha \& Taswan, 2002) dan (Taswan, 2003) menunjukkan bahwa ukuran perusahaan berpengaruh terhadap nilai perusahaan.

Variabel Struktur Modal (DAR) mempunyai nilai thitung 0.476 yang lebih kecil dari ttabel 1.976 dengan tingkat signifikansi ttabel sebesar 0,635 yang lebih besar dari $\alpha=0,05$, 
dengan demikian maka Ho diterima, Ha ditolak. Sehingga dapat disimpulkan bahwa variabel Struktur Modal (DAR) berpengaruh tidak signifikan terhadap Nilai Perusahaan (PRICE) pada perusahaan sektor industri kepariwisataan yang terdaftar di BEI tahun 2013-2018. Hasil penelitian ini sejalan dengan hasil penelitian (Kusumajaya, 2011); (Bukit, 2012) dan (Hamidy, Wiksuana, \& Artini, 2015) yang mengungkapkan bahwa struktur modal memiliki pengaruh positif dan signifikan terhadap nilai perusahaan dan hasil penelitian ini bertentangan dengan penelitian (Gemmill, 2001); dan (Subiyantoro \& Andreani, 2003) yang menyatakan stturktur modal tidak berpengaruh signifikan terhadap nilai perusahaan.

\section{SIMPULAN}

Kesimpulan penelitian ini adalah secara parsial profitabilitas, Kepemilikan institusi dan ukuran perusahaan berpengaruh signifikan terhadap struktur modal sedangkan pertumbuhan perusahaan berpengaruh tidak signifikan terhadap struktur modal pada perusahaan sektor industri kepariwisataan yang terdaftar di BEI tahun 2013-2018. Secara simultan ada pengaruh variabel profitabilitas, kepemilikan institusi, pertumbuhan perusahaan dan ukuran perusahaan terhadap struktur modal pada perusahaan sektor industri kepariwisataan yang terdaftar di BEI tahun 20132018. Secara parsial profitabilitas, Kepemilikan institusi, ukuran perusahaan dan strukturan modal berpengaruh signifikan terhadap Nilai Perusahaan, sedangkan Pertumbuhan perusahaan berpengaruh tidak signifikan terhadap Nilai Perusahaan pada perusahaan sektor industri kepariwisataan yang terdaftar di BEI tahun 2013-2018. Secara simultan profitabilitas, Kepemilikan institusi, ukuran perusahaan, pertumbuhan perusahaan dan struktur modal berpengaruh signifikan terhadap nilai perusahaan pada perusahaan sektor industri kepariwisataan yang terdaftar di BEI tahun 2013-2018. Beberapa saran terkait penelitian ini yaitu variabel penelitian yang digunakan tidak menggunakan proksi namun langsung saja pada variabel yang digunakan sebagai proksi tersebut. Sehingga dalam pembahasannya tidak rancu dalam penyebutannya. Selain itu penelitian ini hanya menggunakan Profitabilitas yang diproksikan dengan Return On Equity (ROE), Kepemilikan institusi (KIS), Ukuran Perusahaan (SIZE), Pertumbuhan perusahaan yang diproksikan dengan Growth Asset (GA), Struktur modal yang diproksikan dengan Debt asset Ratio (DAR) dan Nilai Perusahaan yang diproksikan dengan harga saham (Price), penelitian berikutnya dapat mengunakan variabel lainnya yang dapat mempengaruhi struktur modal dan nilai perusahaan. Perusahaan yang diteliti dalam penelitian ini hanya perusahaan sektor industri kepariwisataan yang listing di BEI dengan jumlahnya sangat terbatas, penelitian berikutnya disarankan untuk menggunakan perusahaan yang lebih variatif yang sudah listing lebih banyak lagi di BEI sehingga ketersediaan data lebih tercukupi.

\section{REFERENSI}

Atmaja, L. S. (2008). Teori dan Praktik Mnajemen Keuangan. Yogyakarta: Andi Offset.

Bhadhuri, S. (2002). Determinants of corporate borrowing: Some evidence from the Indian corporate structure. Journal of Economics and Finance, 26(2), 200-215.

Brigham, E. F., \& Houston, J. F. (2010). Dasar-Dasar Manajemen Keuangan. Jakarta: PT. Salemba Empat.

Brigham, E. F., \& Houston, J. F. (2011). Dasar-dasar Manajemen Keuangan. Jakarta: PT. Salemba Empat.

Brigham, F. ., \& Daves, R. P. (2010). Intermidate Financial Management. New Jersey: Mc Graw Hill Companies Inc.

Bukit, R. B. (2012). Pengaruh Struktur Modal Terhadap Nilai Perusahaan Melalui Profitabilitas: Analisis Data Panel Perusahaan Manufaktur Di Bursa Efek Indonesia. Jurnal Keuangan \& Bisnis, 4(3), 205-218.

Chen, J. J. (2004). Determinants of capital structure of Chinese-listed companies. Journal of 
Business Research, 57(2), 1341-1351. https://doi.org/10.1016/S0148-2963(03)00070-5

Dietrich, A., \& Wanzenried, G. (2010). Determinants of Bank Profitability Before and During the Crisis: Evidence from Switzerland. Retrieved from https://ssrn.com/abstract=1370245

Ernawati, D., \& Widyawati, D. (2015). Pengaruh profitabilitas, Leverage dan ukuran perusahaan terhadap nilai perusahaan. Jurnal Ilmu Dan Riset Akuntansi, 4(4), 1-17.

Ferri, M. G., \& Jones, W. H. (1979). Determinats Of Financial Structure A New Methhodological Approach. The Journal Of Financial, 34(3), 631-644. https://doi.org/10.2307/2327431

Fraser, L. M., \& Ormiston, A. (2004). Memahami Laporan Keuangan. Jakarta: PT Indeks.

Gemmill, G. (2001). Capital Structure and Firm Value: A Study of Split-Capital Closed-End Funds in the UK. SSRN Electronic Journal, 1-28. https://doi.org/10.2139/ssrn.268921

Gultom, R., Agustina, \& Wijaya, S. W. (2013). Analisis Faktor-Faktor yang Mempengaruhi Nilai Perusahaan pada Perusahaan Farmasi di Bursa Efek Indonesia. Jurnal Wira Ekonomi Mikroskil, 3(1), 51-60.

Hamidy, R. R., Wiksuana, I. G. B., \& Artini, L. G. S. (2015). Pengaruh Struktur Modal Terhadap Nilai Perusahaan dengan Profitabilitas Sebagai Variabel Intervening pada Perusahaan Properti dan Real Estate di Bursa Efek Indonesia. E-Jurnal Ekonomi DanBisnis Universitas Udayana, 4(10), 665-682.

Haneef, S., Riaz, T., Ramzan, M., Rana, M. A., Ishaq, H. M., \& Karim, Y. (2012). Impact of Risk Management on Non-Performing Loans and Profitability of Banking Sector of Pakistan. International Journal of Business and Social Science, 3(7), 307-315.

Harahap, S. S. (2016). Analisis Kritis Laporan Keuangan. Jakarta: Rajawali Pers.

Harjito, A., \& Martono. (2008). Manajemen Keuangan. Yogyakarta: Ekonisia.

Hartanty, E. (2013). Pengaruh Struktur Modal, Pertumbuhan Perusahaan dan Return on Investment (ROI) terhadap Nilai Perusahaan pada Perusahaan yang Terdaftar di Bursa Efek Indonesia Periode 2008-2012. Jurusan Akuntansi, Fakultas Ekonomi, Universitas Maritim Raja Ali Haji (UMRAH) Tanjungpinang.

Hatta, A. J. (2002). Faktor-faktor yang Mempengaruhi Kebijakan Dividen: Investifasi Pengaruh Teori Stakeholder. JAAI, 6(2), 1-22.

Helfert, E. A. (1997). Teknik Analisis Keuangan. Jakarta: Erlangga.

Herawaty, V. (2009). Peran praktek corporate governance sebagai moderating variable dari pengaruh earnings management terhadap nilai perusahaan. Jurnal Akuntansi Dan Keuangan, 10(2), 97-108.

Hermawan, S., \& Maf'ulah, A. N. (2014). Pengaruh Kinerja Keuangan Terhadap Nilai Perusahaan Dengan Pengungkapan Corporate Social Responsibility Sebagai Variabel Pemoderasi. Jurnal Dinamika Akuntansi, 6(2), 103-118.

Indriyatni, L. (2012). Analisis Faktor-Faktor yang Mempengaruhi Nilai Perusahaan Dengan Struktur Modal Sebagai Mediasi Pada Perusahaan Development Property yang Terdaftar Di Bursa Efek Indonesia 2007-2010. Fokus Ekonomi, 7(1), 57-69.

Ismiyanti, F., \& Hanafi, M. M. (2004). Struktur Kepemilikan, Risiko, Dan Kebijakan Keuangan: Analisis Persamaan Simultan. The Journal of Indonesian Economy and Business, 19(2). https://doi.org/10.22146/jieb.6595

Jensen, M. C., \& Meckling, W. H. (1976). Theory of the firm: Managerial behavior, agency costs and ownership structure. Journal of Financial Economics, 3(4), 305-360. https://doi.org/10.1016/0304-405X(76)90026-X

Jufrizen, J., \& Al-Fatin, I. N. (2020). Pengaruh Debt To Equity Ratio, Return On Equity, Return On Assets Dan Ukuran Perusahaan Terhadap Nilai Perusahaan Pada Perusahaan Farmasi. Jurnal Humaniora: Jurnal Ilmu Sosial, Ekonomi dan Hukum, 4(1), 183-195. 
Jufrizen, J., \& Asfa, Q. (2015). Pengaruh Profitabilitas Dan Kebijakan Hutang Terhadap Nilai Perusahaan Pada Perusahaan Farmasi Yang Terdaftar Di Bursa Efek Indonesia Periode 2010-2013. Jurnal Kajian Manajemen Bisnis, 4(2).

Jumingan. (2018). Analisis Laporan Keuangan. Jakarta: Rajawali Pers.

Kasmir. (2010). Pengantar Manajemen Keuangan. Jakarta: Kencana Prenada Media Grup.

Kasmir. (2012). Analisis Laporan Keuangan. Jakarta: Rajawali Pers.

Krishnan, V. S., \& Moyer, R. C. (1996). Determinants of Capital Structure: An Empirical Analysis of Firms In Industrialized Countries. Managerial Finance, 22(2), 39-55. https://doi.org/10.1108/eb018548

Kusuma, G. I., Suhadak, \& Arifin, Z. (2012). Analisis Pengaruh Profitabilitas (profitability) Dan Tingkat Pertumbuhan (Growth) Terhadap Struktur Modal dan Nilai Perusahaan (Studi pada Perusahaan Real Estate and Property yang Terdaftar di Bursa Efek Indonesia (BEI) Periode 2007-2011). Malang.

Kusumajaya, D. K. O. (2011). Pengaruh Struktur Modal dan Pertumbuhan Perusahaan terhadap Profitabilitas dan Nilai Perusahaan pada Perusahaan Manufaktur di Bursa Efek Indonesia. Program Magister Studi Manajemen Program Pascasarjana. Fakultas Ekonomi Universitas Udayana.

Kusumawati, W. S., Topowijono, \& Endang, M. W. (2016). Pengaruh Profitabilitas, Kebijakan Dividen Dan Risiko Sistematis Terhadap Harga Saham (Studi Pada Perusahaan Manufaktur Yang Listing Di BEI Periode 2012-2014). Jurnal Administrasi Bisnis (JAB), 35(2), 127135.

Languju, O. (2016). Pengaruh Return On Equity, Ukuran Perusahaan, Price Earning Ratio dan Struktur Modal terhadap Nilai Perusahaan Property and real estate terdaftar di Bursa Efek Indonesia. Jurnal Berkala Ilmiah Efisiensi, 16(2), 387-398.

Mai, M. U. (2006). Analisis Variabel-Variabel yang Mempengaruhi Struktur Modal Pada Perusahaan-Perusahaan LQ-45 di Bursa Efek Jakarta. Ekonomika, 2(2), 228-243.

Manoppo, H., \& Arie, F. V. (2016). Pengaruh Struktur Modal, Ukuran Perusahaan dan Profitabilitas Terhadap Nilai Perusahaan Otomotif yang Terdaftar di Bursa Efek Indonesia Periode 2011-2014. Jurnal EMBA: Jurnal Riset Ekonomi, Manajemen, Bisnis Dan Akuntansi, 4(2), 485-497.

Mas'ud, M. (2008). Analisis Faktor-Faktor Yang Mempengaruhi Struktur Modal Dan Hubungannya Terhadap Nilai Perusahaan. Manajemen Dan Bisnis, 7(1), 69-83.

Moh'd, M. A., Perry, L. G., \& Rimbey, J. N. (1998). The Impact of Ownership Structure on Corporate Debt Policy: A Time-Series Cross-Sectional Analysis. The Financial Review, 33(3), 85-98.

Munawir, S. (2018). Analisa Laporan Keuangan. Yogykarta: Liberty.

Nurlela, R., \& Islahudin. (2008). Pengaruh Corporate Social Responsibility terhadap Nilai Perusahaan dengan Prosentase Kepemilikan Manajemen sebagai Variabel Moderating. In Simposium Nasional Akuntansi XI (pp. 1-25).

Ogbulu, O. M., \& Emeni, F. K. (2012). Determinants of Corporate Capital Structure in Nigeria. International Journal of Economics and Management Sciences, 1(10), 81096.

Ozkan, A. (2001). Determinants of Capital Structure and Adjustment to Long Run Target: Evidence From UK Company Panel Data. Journal of Business Finance \& Accounting, 28(1-2), 175-198. https://doi.org/10.1111/1468-5957.00370

Pakpahan, R. (2010). Pengaruh Faktor-faktor Fundamental dan Kebijakan Dividen terhadap Nilai Perusahaan. Ekspansi : Jurnal Ekonomi, Keuangan, Perbankan Dan Akuntansi, 2(2), 211-227.

Parul, K. (2012). Managing non-performing assets in commercial banks. GianJyoti E-Journal, $1(3), 22-35$. 
Pinasti, W. F., \& Mustikawati, R. I. (2018). Pengaruh CAR, BOPO, NPL, NIM Dan LDR Terhadap Profitabilitas Bank Umum Periode 2011-2015. Jurnal Nominal, 7(1), 126-142.

Prabansari, Y., \& Kusuma, H. (2005). Faktor-Faktor yang Mempengaruhi Struktur Modal Perusahaan Manufaktur Go Public di Bursa Efek Jakarta. Yuke Prabansari, Hadri Kusuma, (Khusus), 1-15. https://doi.org/10.20885/js.v0i0.935

Prasetyo, A. H. (2011). Valuasi Perusahaan. Jakarta: PPM.

Rahmawati, A. D. (2015). Pengaruh Ukuran Perusahaan, Profitabilitas, Struktur Modal, Dan Keputusan Investasi Terhadap Nilai Perusahaan (Studi Pada Perusahaan Sektor Properti, Real Estate, Dan Building Construction Yang Terdaftar Di Bursa Efek Indonesia (Bei) Periode 2010-2013). Jurnal Administrasi Bisnis (JAB), 23(2), 1-7.

Riyanto, B. (2013). Dasar-Dasar Pembelanjaan Perusahaan. Yogyakarta: BPFE.

Rustendi, T., \& Jimmi, F. (2008). Pengaruh Hutang dan Kepemilikan Manajerial Terhadap Nilai Perusahaan Pada Perusahaan Manufaktur (Survey Pada Perusahaan Manufaktur Yang Tercatat Di Bursa Efek Jakarta). Jurnal Akuntansi FE Unsil, 3(1), 411-422.

Safitri, M. (2015). Analisis Pengaruh Struktur Modal, Likuiditas Dan Efektivitas Terhadap nilai Perusahaan Dan Profitabilitas Sebagai Variabel Intervening Pada Perusahaan Manufaktur. Diponegoro University.

Safrida, E. (2008). Pengaruh Struktur Modal, Pertumbuhan Perusahaan, Profitabilitas Dan Ukuran Perusahaan Terhadap Nilai Perusahaan (Studi Pada Perusahaan Manufaktur Di Indonesia). Jumal Akuntansi Riset, Prodi Akuntansi UPI, 3(2), 552-568.

Saidi. (2004). Laporan Keuangan (4th ed.). Yogyakarta: Liberty.

Septiono, R. W., Suhadak, \& Darminto. (2013). Analisis Faktor Mikro Terhadap Struktur Modal Dan Nilai Perusahaan. Jurnal Administrasi Bisnis (JAB), 2(1), 138-151.

Setiawan, R. (2006). Faktor-faktor yang mempengaruhi struktur modal dalam persfektif packing order theory studi pada industri makanan dan minuman pada industri makanan dan minuman di BEJ. Majalah Ekonomi, 16(3), 318-331.

Soliha, E., \& Taswan. (2002). Pengaruh Kebijakan Hutang terhadap Nilai Perusahaan serta Beberapa Faktor yang Mempengaruhinya. Jurnal Bisnis Dan Ekonomi, 9(2), 149-163.

Sparta. (2000). Pengaruh Faktor-faktor Fundamental Lembaga Keuangan Bank terhadap Harga Sahamnya di Bursa Efek Indonesia. Jurnal Akuntansi FE Untar, 4(1).

Subiyantoro, E., \& Andreani, F. (2003). Analisis Faktor-Faktor Yang Mempengaruhi Harga Saham (Kasus Perusahaan Jasa Perhotelan yang Terdaftar di Pasar Modal Indonesia). Jurnal Manajemen \& Kewirausahaan, 5(2), 171-180.

Suharli, Michell. (2006). Studi Empiris Terhadap Faktor Yang Mempengaruhi Nilai Perusahaan Pada Perusahaan Go Public Di Indonesia. MAKSI, 6, 243-256.

Suharli, Michelli. (2006). Studi Empiris Terhadap Faktor Yang Mempengaruhi Nilai Perusahaan Pada Perusahaan Go Public Di Indonesia. Jurnal Maksi, 6(1), 23-41.p

Sukirni, D. (2012). Kepemilikan Manajerial, Kepemilikan Institusional, Kebijakan Deviden Dan Kebijakan Hutang Analisis Terhadap Nilai Perusahaan. Accounting Analysis Journal, 1(2), $1-12$.

Sundari, T. W., \& Utami, W. (2013). Pengaruh Kinerja Keuangan Terhadap Nilai Perusahaan Dengan Kebijakan Dividen. MIX: Jurnal Ilmiah Manajemen, 3(3), 309-321.

Suranta, E., \& Midiastuty, P. P. (2003). Analisis Hubungan Struktur Kepemilikan Manajerial, Nilai Perusahaan dan Investasi Dengan Model Persamaan Linear Simultan. The Indonesian Journal of Accounting Research (IJAR), 6(1).

Tarjo. (2008). Pengaruh Konsentrasi Kepemilikan Institusional dan Leverage Terhadap Manajemen Laba, Nilai Pemegang saham serta Cost of Equity Capital. In Prosiding SNA Simposium Nasional Akuntansi (p. 11).

Taswan, T. (2003). Analisis Pengaruh Insider Ownership, Kebijakan Hutang dan Deviden 
Terhadap nilai Perusahaan serta Faktor-faktor yang Mempengaruhinya. Jurnal Ekonomi Dan Bisnis, 10(2), 162-181.

Veithzal, A. P., Sudarto, S., Basir, S., \& Rivai, V. (2013). Commercial Bank Management Manajemen Perbankan. Jakarta: Rajawali Pers.

Wahyudi, U., \& Pawestri, H. P. (2006). Implikasi Struktur Kepemilikan Terhadap Nilai Perusahaan: Dengan Keputusan Keuangan Sebagai Variabel. In Simposium Nasional Akuntansi IX (pp. 1-25). Padang, 23-26 Agustus 2006.

Weston, J. F., \& Brigham, F. E. (2005). Dasar-dasar Manajemen Keuangan. Jakarta: Erlangga.

Weston, J. F., \& Copeland, T. E. (2010). Manajemen Keuangan (9th ed.). Jakarta: Binarupa Aksara.

Yogianta, C. W. E. (2013). Analisis Pengaruh CAR, NIM, LDR, NPL dan BOPO Terhadap Profitabilitas Studi Pada Bank Umum yang Go Publik di Bursa Efek Indonesia Periode Tahun 2002-2010. Jurnal Bisnis STRATEGI, 22(2), 94-111.

Zuhroh, I. (2019). The Effects of Liquidity, Firm Size, and Profitability on the Firm Value with Mediating Leverage. In The 2nd International Conference on Islamic Economics, Business, and Philanthropy (ICIEBP) (pp. 203-230). https://doi.org/10.18502/kss.v3i13.4206 